\title{
"Boletín de los Observatorios de Tonantzintla y Tacubaya" 1952 to 1972: Preliminary results of a bibliometric study
}

\author{
María Elena Jiménez-Fragozo ${ }^{1, \star}$ and Hector Aceves ${ }^{1}$ \\ ${ }^{1}$ Instituto de Astronomía. UNAM. Ensenada. México
}

\begin{abstract}
We analyzed the scientific production of astronomers published in the first Mexican journal of astronomy, the Boletín de losObservatorios de Tonantzintla y Tacubaya (BOTT), from 1952 to 1972. The bibliometric behavior of the BOTT is provided, identifying the most productive authors, article usage, as well as impact and visibility.
\end{abstract}

\section{Introduction}

Editing the publications of the Mexican astronomical community started in 1880 with the first volume of the AnuarioAstronómico Nacional, which continues to be published today. Ten years later, in 1890 publication of the BoletíndelObservatorioAstronómico de Tacubaya started,endinged in 1896. In 1952, fifty six years later and in a different Mexican historical time, the Boletín de losObservatorios de Tonantzintla y Tacubaya [BOTT] was published [1].

The first issue of the BOTT was published in January 1952 with a 9 page article in Spanish, with an abstract written in English, by the Mexican astronomer Guillermo Haro. The first five issues copies of the BOTT were mimeographed, a very popular, artisanal and inexpensive way to print at that time and it was disseminated to the international astronomical community by postal mail (Fig. 1).

The BOTT was totally financed by the Instituto de Astronomía of the Universidad Nacional Autónoma de México (UNAM). The back of the title page of volume 5, number 35 (1970), specifies that the BOTT was partially sponsored by the Instituto Nacional de la InvestigaciónCientífica and for the first time included the names of the editorial board members: Guillermo Haro, Paris Pismis and Silvia Torres-Peimbert.

The BOTT was published from January 1952 to December 1972, and it was the main publication where Mexican astronomers published their research results. It was founded and edited throughout the 20 years mainly by Guillermo Haro, "to publish only the original astronomical research, which, were not being published elsewhere" [2]. The main objective of this work is to show preliminary results of the BOTT bibliometric behavior.

\section{Methodology}

The BOTT was not a peer-reviewed publication, the works werenot included in any commercial databases, thereforethe sources used for this research were NASA's Astrophysics Data Systems and

^e-mail: jimenez@astro.unam.mx ORCID: 0000-0002-6654-5148 

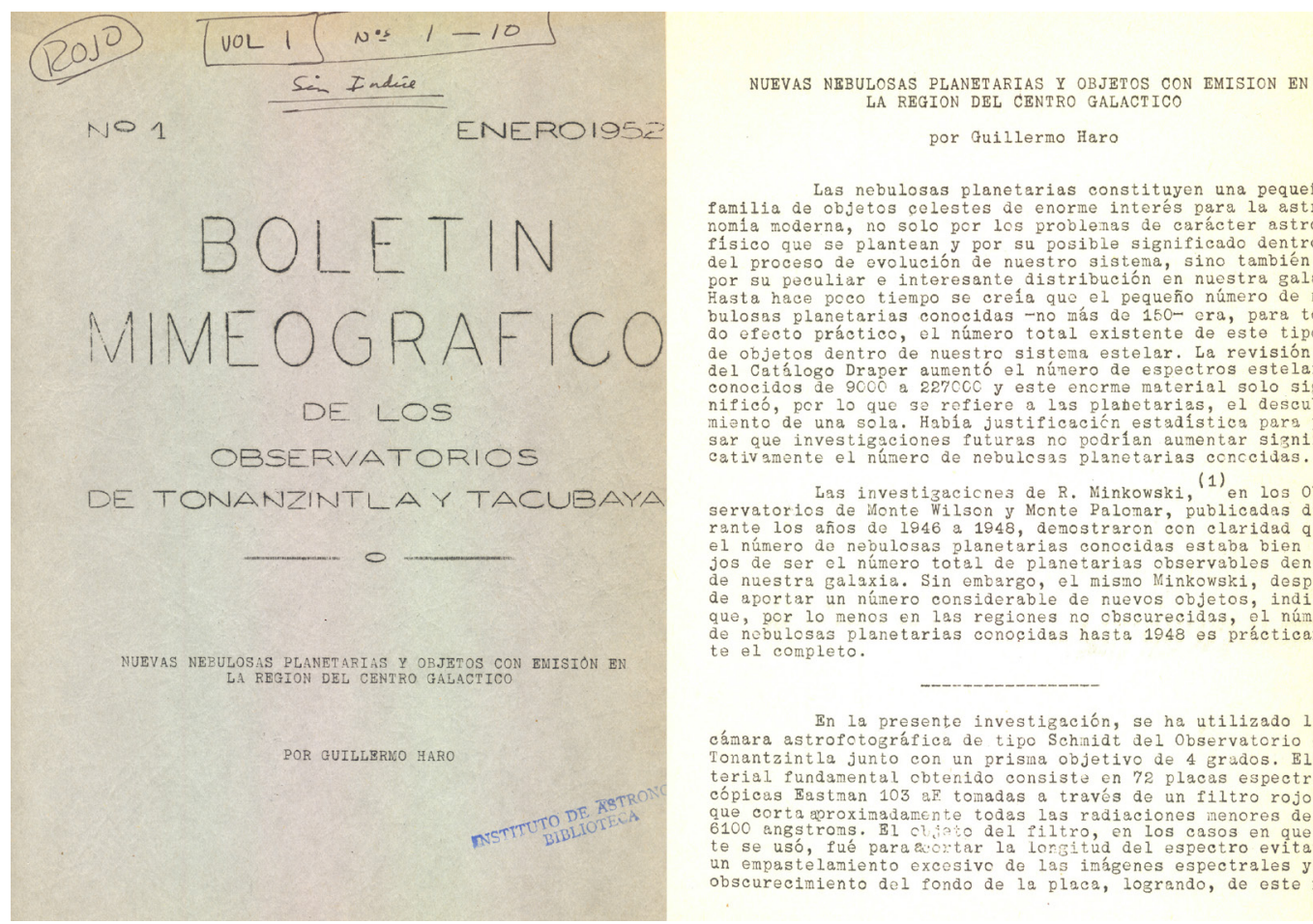
Las nebulosas planetarias constituyen una pequeña
familia de objetos celestes de enorme interés para la astro nomia moderna, no solo por los problenas de caracter astrofísico que se plantean, y por su posible significado dentro del proceso de ovolución de nuestro sistema, sino también Hasta hace poco tiempo se creía que el pequeño número de ne bulosas planetarias conocidas - no más de 150- era, para todo efecto práctico, el número total existente de este tipo de objetos dentro de nuestro sistema estelar. La revisión del Catálogo Draper aumentó el número de espectros estelares conocidos de 9000 a 22 roco y este enorme material solo signitiob, por 10 que se reflere a las planetarias, el descubr sar oue investigaciones futuras no nodrian aumentar sionificativamente el número de nebulcsas planetarias conccilas. Las investigacicnes de R. Minkowski, (1) en los Observatorios de Monte Wilson y Monte Palomar, publicadas durante los años de 1946 a 1948, demostraron con claridad que el numero de nebulosas planetarias conocidas estaba bien le jos de ser el numero total de planetarias observables dentro de nuestra galaxia. Sin embargo, el mismo Minkowski, después de aportar un número considerable de nuevos objetos, indica que, por lo menos en las regiones no obscurecias, el número de nebulosas planetarias conocidas hasta 1948 es prácticamen

En la presente investigación, se ha utilizado la cámara astrofotográfica de tipo Schnidt del observatorio de Tonantzintla junto con un prisma objetivo de 4 grados. Bl ma terial fundamental obtenido consista en 72 placas espectroscópicas Eastman 103 aF tomadas a través de un filtro rojo que corta aproximadamente todas las radiaciones menores de 6100 angstroms. Fl cliato del piltro, en los casos en que és un empastelamiento excesivo de las imágenes espectrales y el obscurecimiento del fondo de la placa, logrando, de este mo-

Figure 1. First issue cover and first article title page in the BOTT.

the BOTT itself, both in the printed version available at our Library as well as digital versions available online. ${ }^{1}$ The BOTT published 176 papers in 6 volumes with 1,698 references and received 2,407 citations until April 2017. In order to facilitate our study three databases were made, one for scientific production, a second one for the references and a third one for citations (results which are not included in this work). Standardizing authors, titles and institutions in order to appear under a single

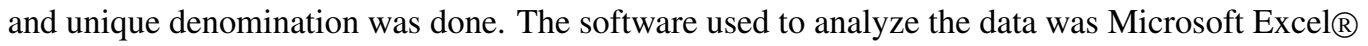

\section{Results}

Publication date and the number of articles published by volume number were found to be irregularly distributed in time. Some of the volumesincluded just one article. However, in 1970 the publications reached 21 articles, being the highest number of articles published in a year in the BOTT (Fig. 2).

Principal author analysis shows that 102 of the 176 articles published in the BOTT were written by 6 authors; a 57.95\% of the total scientific production reported (Fig. 3, left)

A strong collaboration between Mexican and American astronomers, from prestigious observatories and university departments, was observed. Collaborations with other nations included astronomers from the former Soviet Union, N. Ireland, Argentina and Chile (Fig. 3, right).

\footnotetext{
${ }^{1}$ www.astroscu.unam.mx/bott
} 


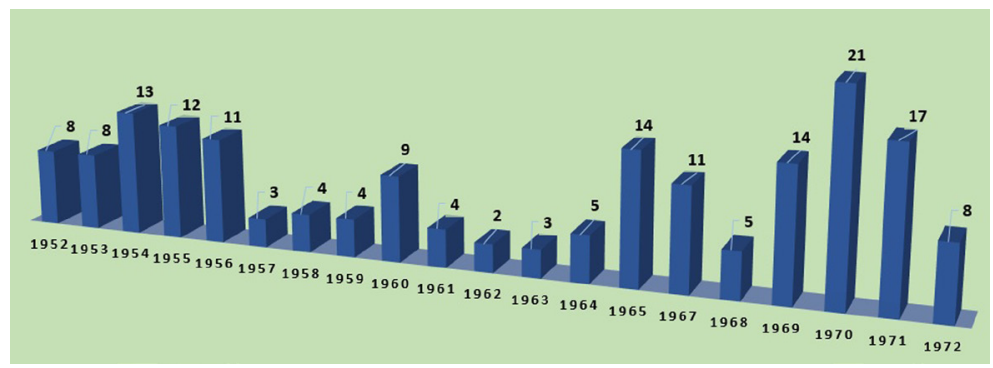

Figure 2. Number of articles published per year.
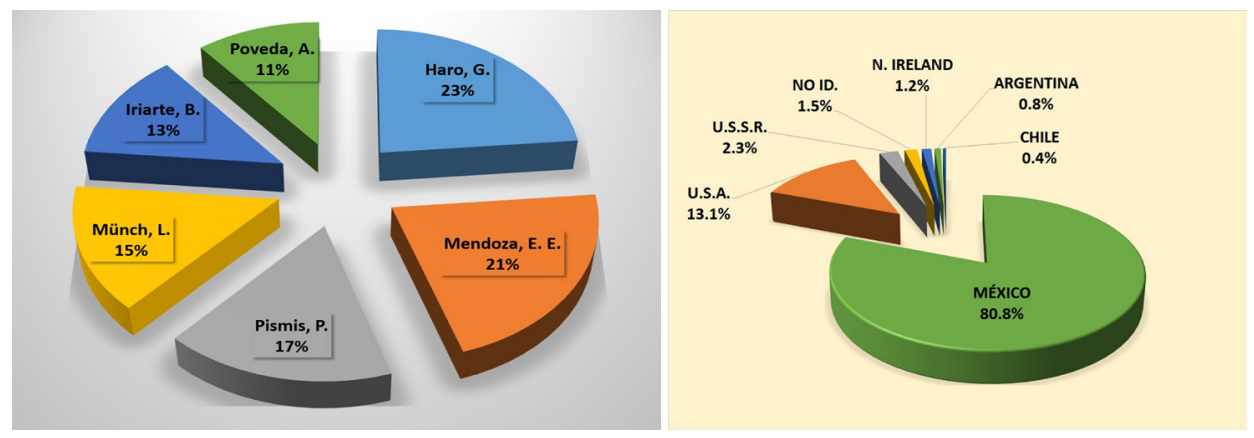

Figure 3. (Left) First author distribution. (Right) Distribution of BOTT publications by authors' affiliation.

The BOTT published original works on mainstream topics in astronomy and astrophysics. Six articles received 1,123 cites, which means $46.7 \%$ of the 2,407 citations received. The distribution of Authors, Article Title, Number of Citations received and percentage is shown in Fig. 4 .

\begin{tabular}{|l|l|cc|}
\hline \multicolumn{1}{|c|}{ ARTICLE TITLE } & & \\
\hline \multicolumn{1}{|c|}{ AUTHOR } & \multicolumn{1}{c|}{ CITATIONS } & $\%$ \\
\hline Peimbert, M. & Chemical Abundances in Galactic HII Regions & 393 & 16.33 \\
\hline Poveda, A. & Run-away Stars as the Result of the Gravitational Collapse of Proto-stellar Clusters & 175 & 7.27 \\
\hline Johnson, H. L. & The colors, Bolometric corrections and effective temperatures of the bright stars & 174 & 7.23 \\
\hline Mendoza, E. E. & Multicolor Photometry of Stellar Aggregates & 155 & 6.44 \\
\hline Mitchell, R. I. & Photoelectric Photometry of Cepheid Variable Stars & 119 & 4.94 \\
\hline Haro, G. & Preliminary Note on Blue Galaxies with emission lines & 107 & 4.45 \\
\hline & & 1123 & 46.66 \\
\hline
\end{tabular}

Figure 4. Distribution of the six most cited articles published in the BOTT.

The Bradford's law was applied to the total data sample of references cited on the BOTT. More than half of the references (59.48\%) are in a core list of six journals titles, that included the BOTT, as shown in Fig. 5. The latter indicates that astronomers who published in the BOTT used mainstream science journals of astronomy and astrophysics.

The first scientific document published in the BOTTwritten by Mexican women astronomers, was written by Guillermina and Graciela González (who were sisters) in 1952 entitled: "Estrellas de altaluminosidaden las vecindades de las constelaciones del Cisne y Cefeo" (NASA ADS title: A finding list of high luminosity stars around Cygnus and Cepheus); see Figure 6. 


\begin{tabular}{|c|c|c|c|c|c|c|c|}
\hline Journals & Docs. & No. docs. & Cumulative Journals & Cumulative docs. & $\%$ Cumulative docs. & \%Cumulative Journals & JOURNAL TITLES \\
\hline 1 & 585 & 585 & 1 & 585 & 34.45 & 0.40 & The Astrophysical Journal \\
\hline 1 & 199 & 199 & 2 & 784 & 46.17 & 0.80 & Boletin de los Observatorios Tonantzintla y Tacubaya \\
\hline 1 & 67 & 67 & 3 & 851 & 50.12 & 1.20 & The Astronomical Journal \\
\hline 1 & 64 & 64 & 4 & 915 & 53.89 & 1.59 & Monthly Notices of the Royal Astronomical Society \\
\hline 1 & 60 & 60 & 5 & 975 & 57.42 & 1.99 & Publications of the Astronomical Society of the Pacific \\
\hline 1 & 35 & 35 & 6 & 1010 & 59.48 & 2.39 & The Astrophysical Journal Supplement Series \\
\hline
\end{tabular}

Figure 5. Journals used by astronomers publishing in the BOTT.

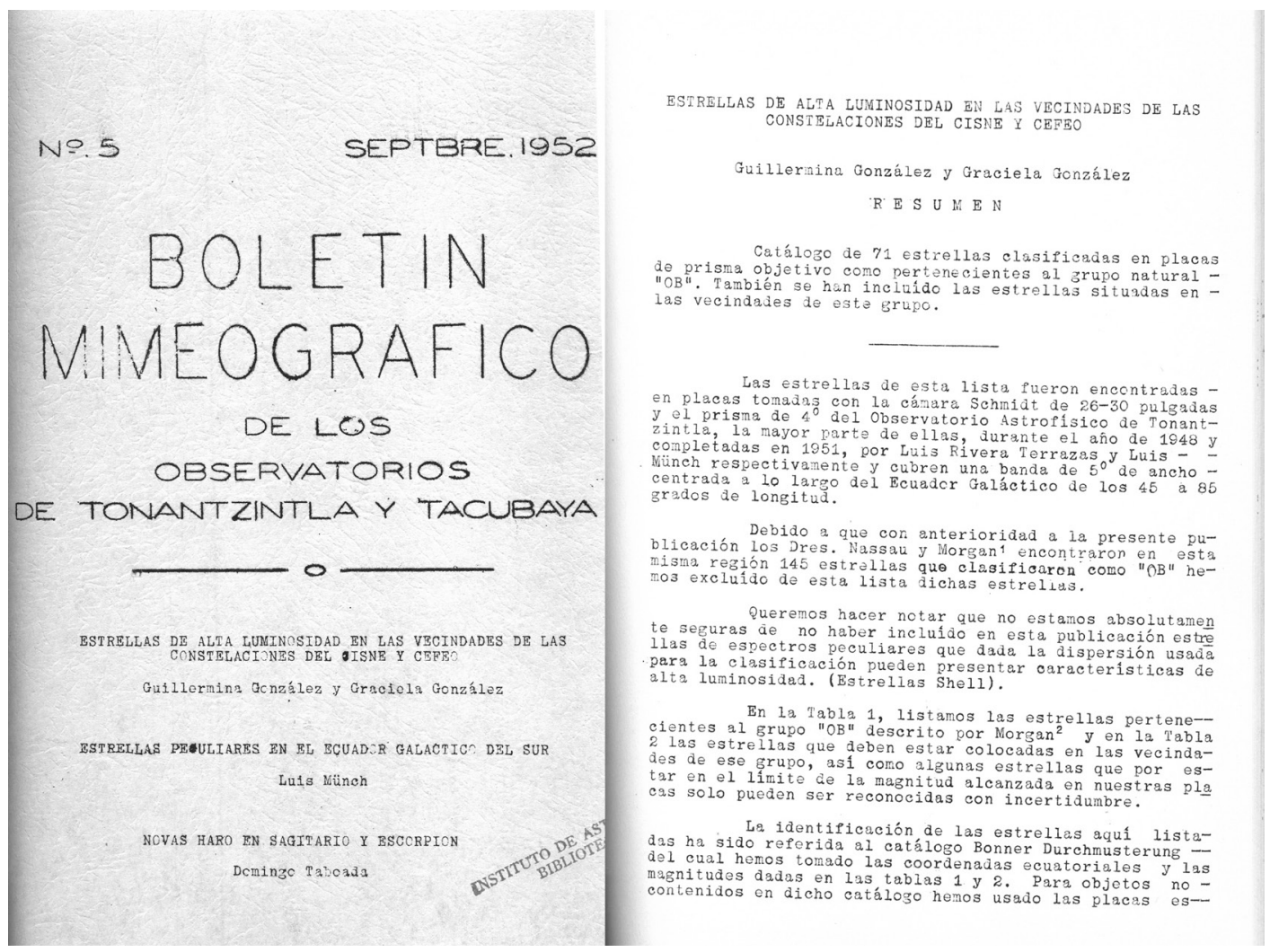

Figure 6. First document published in the BOTT by Mexican women astronomers.

The BOTT had a strong presence of women with 5 as principal authors. The gender distribution of principal authors in the BOTT indicates that 31 articles of the 176 articles were written by a woman; that is a $17.6 \%$. Women authors' distribution is shown in Fig. 7. 


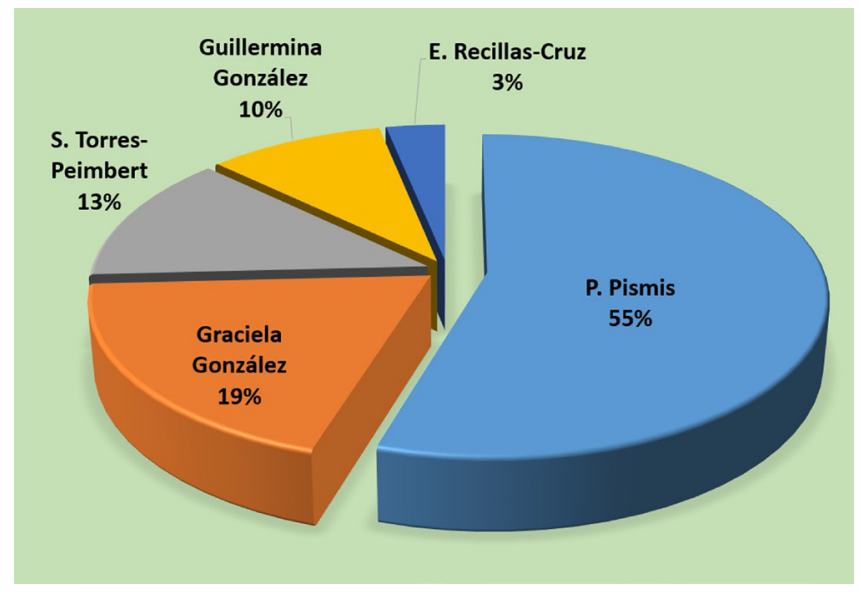

Figure 7. Distribution of the BOTT publications by women as first author.

\section{Final Remarks}

- An emerging relationship with Latin American and international astronomers was initiated by the BOTT; this was confirmed by the results of the study of the Revista Mexicana de Astronomía y Astrofísica 1976-2000 by Mata Acosta [1]

- The BOTT also published the first research articles on optics in México [3].

- A complete citation analysis is ongoing and a paper is being prepared for publication.

- The BOTT and Mexican astronomy was very open to female research, as indicated by the publication of works by Pismis, the González Sisters, Torres-Peimbert (current president of the IAU) and others. A study on the participation of women in astronomy in México at the middle of the previous century is underway.

- A study of the recent Mexican scientific production in astronomy and astrophysics is planned in order to search patterns of coauthorship and international collaborations.

\section{Acknowledgments}

This research has made use of NASA's Astrophysics Data System Bibliographic Services. We thank the Instituto de Astronomía at Ensenada, of the Universidad Nacional Autónoma de México for support to carry out this work.

\section{References}

[1] G.V. Mata Acosta, Comportamientobibliométrico de la Revista Mexicana de Astronomía y Astrofísica 1976-2000. (UNAM, BA Thesis, Mexico, 2001)

[2] S. Torres-Peimbert, O. López-Cruz, M. Peimbert Historictical Note in Highlights of Boletín de los Observatorios de Tonantzintla y Tacubaya, edited by S. Torres-Peimbert, O. López-Cruz (2011), Vol. 39 of Revista Mexicana de Astronomia y Astrofisica Conference Series, p. xi-xii

[3] A. Cornejo Rodrígue, The First Years of Optics in Mexico and the role of the Boletín de los Observatorios de Tonantzintla y Tacubaya on its development in Highlights of Boletín de los Observatorios de Tonantzintla y Tacubaya, edited by S. Torres-Peimbert, O. López-Cruz (2011), Vol. 39 of Revista Mexicana de Astronomia y Astrofisica Conference Series, p. 109-115 
